\title{
REVIEW
}

UDC 58.036:577/.112/.152.1./19:582.542.11

doi: https://doi.org/10.15407/ubj91.03.005

\section{PHENOLIC COMPOUNDS IN PLANTS: BIOGENESIS AND FUNCTIONS}

\author{
L. M. BABENKO ${ }^{1 凶}$, O. E. SMIRNOV ${ }^{2}$, K. O. ROMANENKO \\ O. K. TRUNOVA ${ }^{3}$ I. V. KOSAKIVSKA ${ }^{1}$
}

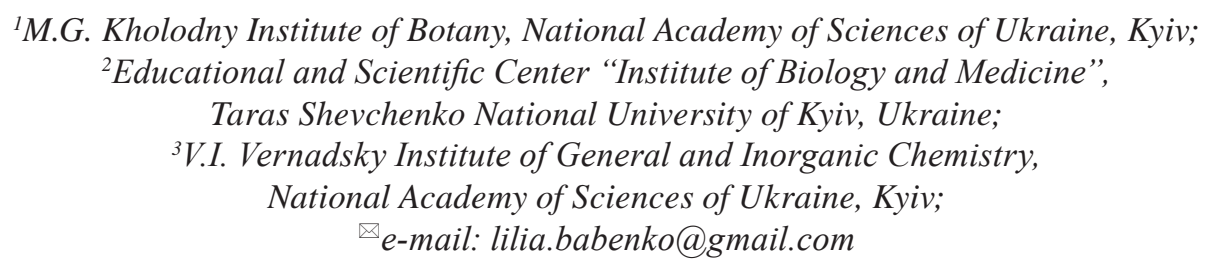

Received: 05 November 2018; Accepted: 14 March 2019

Phenolic compounds (PCS) in plants play an important role in growth control and have antioxidant, structural, attractant, signaling and protective functions. Information on the discovery, study and identification of phenolic compounds in plants, their role in the complex system of secondary metabolites has been analyzed and summarized. The functions of PCs at the macromolecular, cellular as well as organism and population levels are described. The pathways of PCs formation, enzymes responsible for their synthesis and the plasticity of the synthesis in a plant cell are highlighted. The involvement of PCs in the plant breathing, photosynthesis, oxidation-reduction processes and regulation of the plants physiological state are discussed.

Ke ywords: phenolic compounds, phenylalanine, phenylalanine ammonia-lyase, biogenesis, physiological role.

$\mathrm{P}$ lant phenolic compounds combine metabolites that contain one or more phenolic residues and have different numbers of oxygroups and substituents [1]. PCs are found in plants in free and conjugated forms. The complex of PCs is characterized by variety, even within a single plant species: they may include both simple phenols and quinones, phenolcarboxylic acids and their derivatives, flavones, flavonols, catechins, leukoanthocyans [2]. In cells, PCs are localized mainly in a vacuole. However, in young, intensively growing plant tissues, whose cells have weakly developed vacuoles, PCs are chiefly in chloroplasts and nucleus [3]. The accumulation of PCs was shown to depend directly on the functional activity and ultrastructural organization of chloroplasts [4]. Appearing in chloroplasts, in most cases, from phenylalanine or its precursor, shikimic acid, they play an important role in the metabolism of plant cells, and are also involved in chemical interactions between organisms due to allelopathic, antibacterial and antifungicidal activity, regulate the functions of the rhizosphere and participate in the formation of humus [1]. The effects of phenolic compounds are displayed at all levels of biosystems organization, from molecular to ecosystem [5].

One of the most important functions of PCs is their involvement in oxidative-reduction processes [6]. PCs dissociate oxidative phosphorylation, stimulate cell division in a culture in vitro, inhibit seed germination. It is believed that PCs have a role in regulating plant growth and development, since they affect the biosynthesis of indolyl-3-acetic acid [4, 7]. Phenols are the structural components of phytomass. Thus, cinnamic acids are precursors of lignin, an important constituent of a cell wall that encapsulates

(c) 2019 Babenko L. M. et al. This is an open-access article distributed under the terms of the Creative Commons Attribution License, which permits unrestricted use, distribution, and reproduction in any medium, provided the original author and source are credited. 
cellulose components, producing support elements of plant tissues [8]. In response to plant mechanical tissue damages, polymeric phenol compounds of the so-called "wound lignin" are synthesized and a protective layer is formed [9].

\section{Synthesis of phenolic compounds is an integral part of the plant secondary metabolism}

The most numerous group of secondary metabolites is represented by terpenes and has about twenty thousand compounds. The second largest group is that of alkaloids - nitrogen-containing heterocyclic compounds, which combine about ten thousand compounds, and the third one - PCs, which contains about nine thousand compounds [10].

Study of the plant secondary metabolism was started in 1806 after morphine isolation from Papaver somniferum. The development of physico-chemical methods of analysis in the twenties of the twentieth century made it possible to identify various secondary metabolites different in their elemental composition, and further improve identification techniques (mass spectrometry, chromatographic methods) - to conduct qualitative analysis, to separate and identify individual compounds. Using the method of labeled atoms showed that the secondary compounds are formed from products of the primary metabolism. Thus, terpenes are synthesized from acetyl-CoA or glycolysis products, alkaloids are derivatives of amino acids, and PCs - shikimic acid and phenylalanine [11]. Secondary metabolites production was found to involve specific enzymes. The key enzyme of phenolic biosynthesis - phenylalanine ammonia-lyase (PAL; EC 4.3.1.5) [12] was among the first enzymes that had been isolated and purified. However, most physiologists and biochemists believed that PCs are not key components of plant metabolism. In particular, Y. Sachs in the "Experimental Physiology of Plants" ("Handbuch der Experimental Physiologie der Pflanzen") defines phenols - (tannins) - as end products of decomposition that are not involved in the metabolism [13]. The interest of scientists in the study of PCs, namely, flavonoids, increased after Saint-Dyerier discovered in 1936 that flavonoids isolated from the lemon peel strengthen the vascular walls and that offered the opportunity of using them in the pharmacopoeia. Further steps in the study of phenolic metabolism dealt with the cloning of genes coding for the enzymes of their synthesis. Thus, in the eighties of the twentieth century, complementary DNA and cloned genes of phenol biosynthesis enzymes - PAL and chalcone synthase (CHS; ES 2.3.1.74) - were obtained. The development of genomics and plant genetic engineering made it possible to study in more detail the pathways of secondary metabolites biosynthesis. The method of knockout genes and the study of RNA interference in Arabidopsis thaliana plants and other model objects contributed to the further identification of enzymes in phenolic biogenesis and the study of genes responsible for their activity [11].

\section{Biogenesis of phenolic compounds}

Normally, the molecular structures of plant PCs have significant structural differences. Thus, simple phenols have one aromatic ring, oxybenzoic and oxyricic acids - an aromatic ring and an aliphatic side chain, flavonoids - two rings and a tri-carbon fragment, and oxycumarins - benzene and pyrone rings. PCs possess different numbers of oxygroups and differ in their location in the molecule. Depending on that, there are mono-, di- and polyphenols. PCs hydrogen of the oxy group, in some cases, is replaced by methyl or other functional radicals [6].

PCs were found to be synthesized through shikimate and acetate-malonate (polyketide) pathways (Fig.) [4, 14].

Along the shikimate pathway, there are formed phenylpropanoid compounds, including hydroxycinnamic acids and coumarins [10; 15]. The shikimate pathway provides the synthesis of the phenylalanine aromatic amino acid, which is a substrate for the key enzyme of the phenylpropanoid pathway - phenylalanine ammonia-lyase (PAL). The latter deaminates aminocinnamic acid, which is then converted to pcoumarin CoA. This activated p-coumarate reacts with malonyl-CoA involving the key enzyme chalconsintase and production of chalcones. After the product isomerization, naringenin - the predecessor of other flavonoids is produced [14].

The PAL enzyme involved in the transformation of phenylalanine through deamination to transcinnamic acid was first described in the paper [12]. Information on the PAL function was obtained by studying the effects of abiotic and biotic stressors (light, wound, phytopathogens, mineral balance disorders) on the enzyme activity. A de novo correlation was revealed between PAL biosynthesis, PCs accumulation and expression of the corresponding gene [16]. Based on the principle of feedback in plants of transgenic tobacco [17] and post- translational modifications of the enzyme through phospho- 


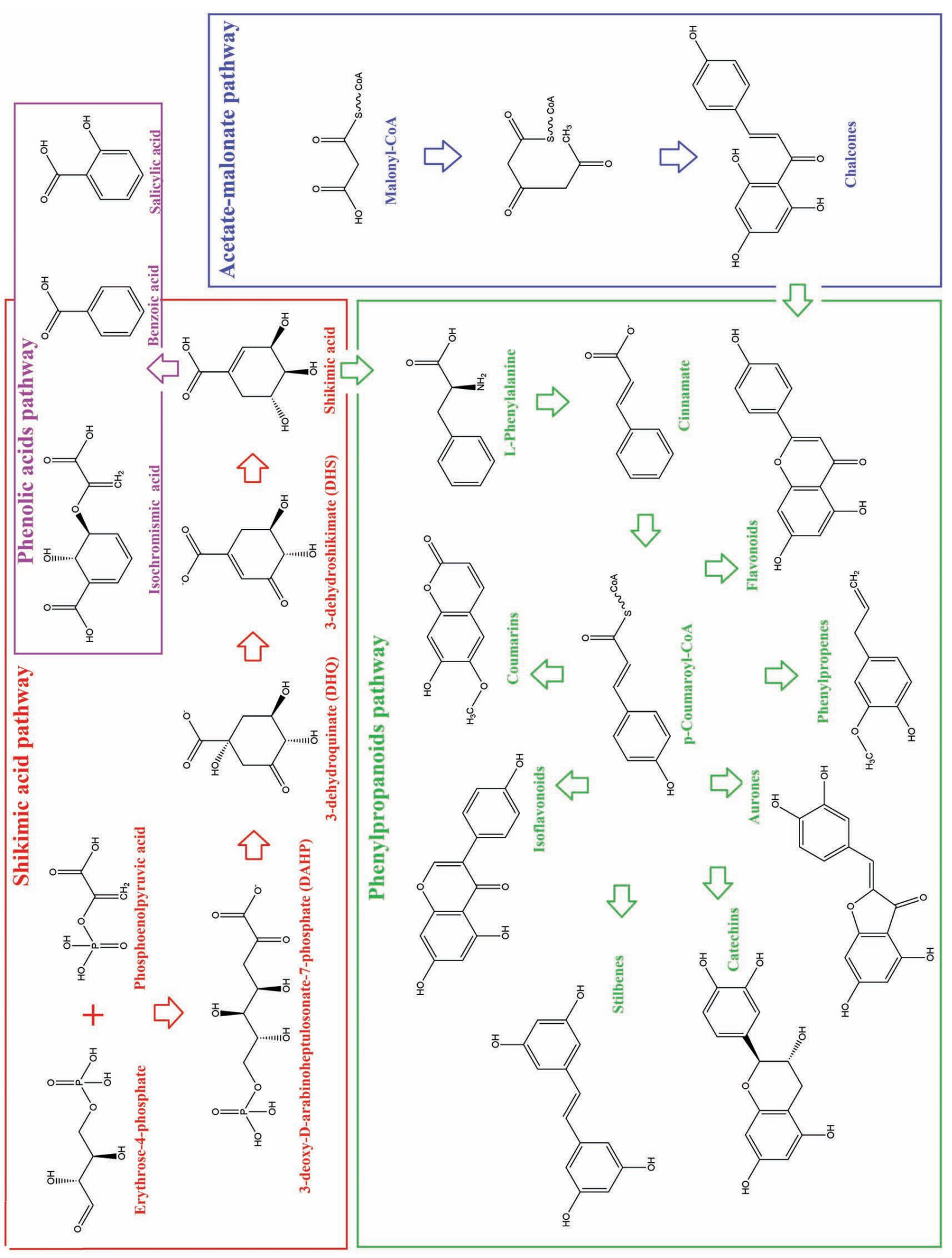

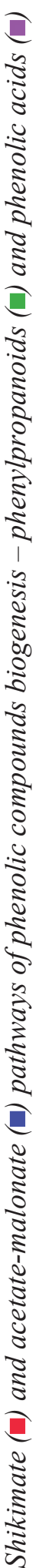


rylation $[18,19]$ there were established other regulatory mechanisms.

The acetate-malonate pathway of PCs synthesis (Fig.) is characteristic for fungi, lichens and microorganisms. Due to its involvement, flowering plants synthesize flavonoids, in which the phenylpropanoid ring is formed through the shikimic pathway, and the other ring is produced through the acetate-malonate pathway [10]. As starting compounds there are used coumarin-CoA and three molecules of malonylCoA, the condensation of which leads to the formation of a chalcone. The reaction is catalyzed with chalkon synthase - the key enzyme of the flavonoid biosynthesis block of polyphenols. The formed tetraoxychalcon is converted to flavanone naringenin that initiates almost all other classes of flavonoids, with the exception of chalcones and dihydrochalcones (Fig.). Flavonoids, which are derivatives of 3 -phenylchroman, also give rise to numerous isoflavonoids (derivatives of 2-phenylchroman) [2]. Intermediates and end-products of the flavonoid pathway were established to accumulate in the places of their synthesis [20].

Thus, in spite of the exceptional diversity of phenolic compounds structures, there are only two main pathways of their biosynthesis - shikimic and acetate-malonate. In higher plants, the shikimic pathway occupies one of the central places in cellular metabolism.

\section{Functions of phenolic compounds}

PCs form intermediate products such as semiquinine radicals and orto-quinines, which interact with proteins and form complexes with metal ions [2]. The antioxidant activity of PCs depends on the structure, in particular on the number and position of the hydroxyl groups and the pattern of substitutions on the aromatic rings. Due to these properties, as well as significant structural diversity, the participation of polyphenols in the life of plants is quite significant [21]. It covers such important processes as photosynthesis, respiration, formation of cell and tissue supporting elements, formation of protective mechanisms, regulation of auxin transport. PCs are involved in oxidative-reduction processes and act as components of electron transport chains in mitochondria and chloroplasts. The content of PCs varies during the plant growth and development (in particular, in the fruit maturation), and in addition to the effect on coloration (anthocyanins), it determines the severity, burningness and taste (capsaicinoids) [22].

\section{PCs involvement in plant respiration, photosynthesis and ontogenesis}

One of the most important functions of the PCs is their involvement in oxidation-reduction processes. V. I. Palladin in 1908, in his book "Das Blut der Pflanzen", suggested that plant respiration is related to the reversible oxidation and the reduction of flavonoids [23]. According to this hypothesis, phenolic compounds are oxidized to quinones with the involvement of polyphenol oxidase (PPO). Quinones, in turn, can be reduced in the presence of protons of the respiratory substrate, becoming available again for PPO. Thus the transfer of hydrogen atoms in the final stages of breathing occurs. Today the role of the polyphenol oxidase system is questioned, since this way of oxidation is not associated with energy storage (the formation of ATP). However, regardless of involvement in respiration, the presence of such system allows the plant cell to oxidize a number of compounds (amino acids, ascorbic acid, cytochrome $\mathrm{C}$, apple and citric acid) by non-enzymatic method. These reactions are important. For example, oxidation of tryptophan with quinones leads to the formation of phytohormones - indolyl-3-acetic acid. Isoprenoid derivatives of hydroquinone - plastoquinone and ubiquinone - are mandatory components of the electron transport chains of chloroplasts and mitochondria [2]. Some flavonols, flavones, chalcones, dihydrochalcones and other PCs representatives act as disconnectors of oxidative phosphorylation in mitochondria [24]. Flavonoids accumulated in chloroplasts, maintain the functional activity of plastids, protecting them from photooxidation and are involved in the detoxification of active forms of oxygen and free radicals [25]. In addition to photosynthesis and breathing, polyphenols are involved in plant growth and development. The signaling role of flavonols (PCs of the flavonoid class) in pollination was established [7]. The formation of the hypothesis about the key role of flavonols as a possible factor in reproductive development was facilitated by numerous data on the occurrence of these substances in the flowers of various plants, as well as on the change in their quantitative and qualitative composition during flowering. It is shown that in the pollen of Nicotiana tabacum flowers, flavonols, campherol and quercetin and their glycosides, which stimulate the germination of pollen and pollen tube, are formed. The flavonols of the mature tobacco pollen promoted the growth of pollen tubes in culture in vitro, while the extracts of immature pistil stigmas 
did not restore the fertility of the pollen, and the extracts of mature stigmas stimulated the growth of pollen tubes [26].

Assumptions that flavonols are involved in the regulation of the pollen germination were made after studies of transgenic petunium plants containing the human sterility gene [27]. The mutants of corn and petunia, defective in the activity of chalconsinase, a key enzyme in the biosynthesis of flavonoids, were sterile because they did not form a functionally active pollen tube $[28,29]$. However, the pollen of mutant plants germinated with the addition of camphorol during pollination, as well as with crossbreeding of a mutant with a wild species (with a flavonol-producing pistil stigma). It was demonstrated that only one type of flavonols, namely aglycones of flavonols, can restore germination of flavonoldeficient pollen. The fertility completely recovered when nanomolar concentrations of kemferol were added to the stigma during pollination [28]. An HPLC analysis revealed kemferol in a mature anther and in wild-type petunia stigma extracts, while the extract from the transgenic plant stigma lost the ability to produce kemferol [28]. The formation of male gametophytes (pollen) of petunia was found to be accompanied by an increase in the content of indolyl-3-acetic acid (IAA) and flavonoids in anther sporophytic tissues. During the pollen formation, both in vitro and in vivo, and germination of pollen grains as well as the growth of pollen tubes in the stigma tissues, the content of IAA and flavonoids increased. A similar pattern was observed within 3-4 hours after a compatible and incompatible pollination. Consequently, the formation of male gametophytes in the column tissues was largely determined by the level of endogenous IAA and flavonoids [7].

It was shown that in the secondary cell walls that are formed during the plant cell differentiation, along with cellulose and hemicellulose fibrils there is a polymer of the phenolic nature, lignin [30]. The formation of lignins is characteristic of all vascular plants. It is believed that due to lignin, the existence of terrestrial vegetation became possible. In woody plants, the content of lignin reaches $20-35 \%$ of dry weight. Formation of the xylem elements and wood durability involve lignin.

\section{PCs in protection against extreme temperatures}

The results of studies on the influence of temperature on the content of PCs are controversial. So, after thermal stress $\left(35^{\circ} \mathrm{C}\right)$ in plants of Solanum lycopersicum, for which the optimum temperature is within $22-26{ }^{\circ} \mathrm{C}$, and after cold stress in plants of Citrullus lanatus whose optimum temperature of growth is within $33-35{ }^{\circ} \mathrm{C}$, there occurred phenols accumulation [31]. It was reported that leaves of cold-sensitive grapes were characterized by a lower content of total phenols than those of resistant varieties [32]. Following cold stress, the content of phenols in the leaves and roots of the grapes increased $[33,34]$. Due to the effects of drought, hyper- and hypothermia, the synthesis of PCs in grape, soybean, Arabidopsis and tomato tissues enhanced [34-36]. At the same time, cold stress was reported to cause no significant changes in the content of PCs in the roots of peas [37], or to lead to its decrease in soybean tissues [38]. During low-temperature adaptation of wheat, there was a significant increase in the content of flavonoids, especially in frost-resistant varieties [39]. With a slight decrease in temperature, the synthesis of anthocyanins in sorghum plants [40] and maize [41] was observed. Under cold stress, antioxidant protection also involves colorless flavonoids. Thus, in Crataegus oxyacantha, cooling resulted in the synthesis of epicatechin and hyperoside [42]. Along with that the flavonoid content in wheat and potato plants affected by low temperatures declines $[43,44]$, while no changes in the content of anthocyanins were detected in the triticale seedlings after the hyperthermia [45]. At the simultaneous action of hyperthermia and water deficit, the number of anthocyanins increased in the seedlings of barley [46]. The induction of anthocyanin synthesis under the influence of low temperature was observed in many plant species [47]. Anthocyanin solutions are able to neutralize the vast majority of reactive oxygen (ROS) and nitrogen species, and make it four times more efficient than equimolar solutions of ascorbate and $\alpha$-tocopherol [48]. However, since PCs accumulate predominantly in vacuoles, questions arise as to their contribution to the neutralization of ROS in vivo [3]. At the same time, it should be noted that there is evidence of the accumulation of a large number of ROSs in vacuoles, where they can be neutralized by low molecular weight antioxidants localized their [42]. Under the influence of excess light and low temperatures, the Arabidopsis mutants, defective in the synthesis of anthocyanins, suffered significant oxidative damages [49]. Along with that, it was reported that the accumulation of anthocyanins following the action of oxidative stress, in particu- 
lar $\mathrm{H}_{2} \mathrm{O}_{2}$, did not occur [50]. However, this does not mean that anthocyanins are not involved in antioxidant defence. It appears that with sufficiently long (two-day) treatment with oxidative stress agents, anthocyanin degraded [51]. Synthesis of quercetin was detected as a response to thermal stress in cucumber plants [42]. The total concentration of flavonoids after the temperature of $-5{ }^{\circ} \mathrm{C}$ in plants of Brassica oleracea remained the same. However, changes in the content of individual flavonoids occurred, in particular, the ratio of quercetin/camphterol increased [52]. A correlation was found between the resistance of cultivated plant varieties and the content of flavonoids [53]. Short-term hypothermia $\left(40^{\circ} \mathrm{C}, 2 \mathrm{~h}\right)$ did not cause significant changes in the content of total phenols and flavonoids in the leaves of frostresistant Triticum spelta, whereas after short-term hyperthermia $\left(40^{\circ} \mathrm{C}, 2 \mathrm{~h}\right)$, an increase in the content of these compounds was observed [54]. Significant differences in the functioning of the defence antioxidant system under normal conditions and after cold hardening occurred in the ethyolated seedlings of rye. Thus, in unhardened seedlings of rye, there was a high content of anthocyanins [55].

\section{PCs in protection against $\mathrm{UV}$ radiation}

Adaptation to UV radiation plays an important role in preventing damage to DNA, photosynthetic and cellular machinery [56]. For the first time, Rosa damascena cells cultured in vitro showed that UVresistant $(254 \mathrm{~nm})$ cells contained 15 times more flavonoids [57]. To date, it has been established that ultraviolet radiation, especially in the short-wave region, stimulates the formation and accumulation of different PCs in tissues of many plant species [56, 58, 59]. Flavonoids were shown to be capable of absorbing UV radiation in the range of $280-320 \mathrm{~nm}$. By passing up to $80 \%$ of the visible light, they absorb 95\% UV radiation [59]. In this case, PCs (primarily flavonoids) accumulate mainly in vacuoles of the epidermal cells, preventing the penetration of UV rays into the inner tissues [60]. It has been demonstrated that the absorption of UV rays by epidermis (at low and average radiation levels) is proportional to the flavonol content in cells [59]. Photosynthetic apparatus protection from excessive illumination involves anthocyanins that serve as an optical filter and protect a saturated photosynthetic electron transport chain from high-energy quanta, increasing the absorption of solar energy within the visible region (380-700 $\mathrm{nm}$ ) by an average of $8-12 \%$ [48].
Anthocyanins protect the photosynthetic apparatus by absorbing excess photons that could be absorbed by chlorophyll b. Although, in general, red leaves absorb more light, their photosynthetic tissues get fewer quanta than green leaves, since the energy absorbed by vacuole, in which the anthocyanins are localized, cannot be transmitted to chloroplasts [42]. The protective effect of PCs during UV irradiation also based on the interaction with peroxides and free radicals that leads to the quenching of free radical reactions occurring in cells affected by UV radiation [58]. The accumulation of anthocyanins in the medicinal plants Ocimum basilicum, Artemisia lercheana and Nigella sativa in response to UV action, salinity and the combined effect of these two factors has been reported [61]. It is interesting that the stress-induced increase in anthocyanin content in Nigella sativa was many times greater than the corresponding values in Ocimum basilicum and Artemisia lercheana. It was established that in plants that accumulate a large number of low molecular weight antioxidants, changes in the activity of antioxidant enzymes were less pronounced [61].

\section{Adaptive-protective functions of phenolic compounds in pathogenesis}

An important function of PCs is the protection of plants from pathogens effects. Constitutive PCs present in the plant tissues and organs have antimicrobial, fungicidal and insecticidal activity [62, 63]. Lignification is one of the most important protective processes occurring in infected and damaged plant tissues and leads to the formation of a physical and chemical barrier for pathogens [8].

Histochemical analysis of the accumulation of soluble PCs and lignin in the leaves of wheat demonstrated that the synthesis of these compounds was observed in the penetration zone of the pathogenic fungus mycelium and correlated with the generation of $\mathrm{H}_{2} \mathrm{O}_{2}$. When getting into apoplasts, stress-induced PCs and monomers of lignin, synthesized in the cytoplasm and plastids, are oxidized and polymerized to lignin in the presence of apoplastic peroxidases. The availability of $\mathrm{H}_{2} \mathrm{O}_{2}$ is believed to be a decisive factor in the polymerization of monolinol to lignin [8].

When a plant is infected by pathogens, the biosynthesis of the plant-specific polyphenol species is activated and it is accompanied by an increase in the enzymatic activity of L-phenylalanine ammonialyase, 4-hydroxylase of trans-cinnamic acid and 
chalcone synthase [9, 64]. At the same time, in the covering tissues, the toxicity of phytoalexins that are toxic to the pathogen, and which are absent in healthy tissues or contained in small quantities, is sharply increasing. The overwhelming majority (more than $80 \%$ ) of phytoalexins is PCs [2]. The most studied phytoalexins are represented by various isoflavonoids, phytoalexins of legumes [65]. In response to the action of the pathogen, the phytoalexins of stilbene, flavan, coumarin, and auron class are also formed [66]. PCs of aqueous plants are shown to be able to suppress the growth of toxic cyanobacteria. Vanillic, protocatechic, ferulic and caffeic acids of Hydrilla verticillata and Vallisneria spiralis, depending on the ratio of the mixture, exhibit additive and synergistic effects in Microcystis aeruginosa growth inhibition [67]. Particular attention is drawn to the study of PCs in the system of host-parasite. In higher plants, normal conditions of existence suggest no harmful effects of various external factors. For phytopathogenic fungi, the necessary condition is to penetrate the tissues of the host plant, form a phytopathosystem for the development and offspring resumption. Drechslera teres culture fluid was demonstrated to contain more than thirty free and conjugated phenolcarboxylic acids required for growth, spore formation and pathogenic and virulent properties. However, the mycelial fungus contained only eight PCs. Consequently, the fungus, while on an artificial nutrient medium, produced PCs that were released outside, and only a small quantity remained in the mycelium [68].

Protective functions are inherent in deterrents (from lat. Deterreo - scare) and antifeedants (from English anti- and feeding) - PCs, which reduce the attractiveness and nutritional value of plant tissues for phytophages [69]. An increase in the content of lignins, tannins, pyrocatechol and ferulic acid in mature leaves makes them unsuitable for feeding larvae and adult insects. In addition, strong protein-tannin complexes are difficult to digest, so mammals, in particular cattle, avoid whole plants or their parts that accumulate tannins [9].

\section{Phenolic compounds - markers of plant chemical taxonomy}

It is thought that PCs first emerged in algae about 500 million years ago. They performed the function of UV protectors [70]. In fungi, with the exception of parasitic, PCs have been investigated fragmentarily. It has been established that the func- tions of PCs of phytopathogenic fungi and plants differ fundamentally. So, in fungi, they are aimed at infecting (optional parasites) or parasitism (obligated mushrooms), whereas in the host plant - to self-defence. In higher plants, pathways of PCs biosynthesis are complex, and that results in the formation of various substances with additional functions. The structure of such compounds is characterized by species and genus specificity, which allows them to be used as chemotaxonomic markers [71, 72]. Thus, due to PCs studies, there were identified morphologically close invasive macrophytes Elodea nuttallii and E. canadensis. Both species contain 7-Odiglyucuronides of luteolin flavones, apigenin and chrysoepythol, as well as phenyl carboxylic acids. The results of identifying the Elodea species on the basis of the ratio between the derivatives of apigenin and chrysoepytol are fully consistent with the data of molecular analysis [73, 74].

\section{Phenolic compounds - regulators of auxin transport}

Auxins, involved in the regulation of root growth, photo- and gravitropism, fertility, move from cell to cell basipetally in stems and acropetally in roots [75]. The application of artificial and natural auxin transport regulators has revealed that changes in flavonoid concentrations cause changes in auxin transport [76]. Flavonoids affect the transport of auxins by modulating the activity of auxins transporters [77]. Changes in the accumulation of specific flavonoid glycosides that occurred in the root extension zone of the mutants of petunia and Arabidopsis, defective in the synthesis of auxin transporters proteins, testified to a cross-flow of metabolic pathways of flavonoids and auxins [77]. The hypothesis regarding the involvement of flavonoids in the regulation of auxin transport in vivo was tested on wild-type Arabidopsis plants and Arabidopsis plants with mutation of a gene coding for the synthesis of the key enzyme of flavonoid biosynthesis chalcon synthase. The growth of wild-type plants in vitro on naringin solution, a precursor of flavonoids with auxin-inhibiting activity, led to inhibition of root growth and lack of gravitropism reaction, similar to synthetic auxin-induced transport effects. Investigation of chalcon synthase defective mutants revealed an increase in auxin transport. However, under the cultivation of plants in the presence of naringin, transport of the hormone was suppressed [76]. The influence of flavonoids on auxins homeostasis was 
established, but as far as the auxin regulation of the flavonoid accumulation is concerned, the evidence is insufficient [78].

Auxins are an integral part of the regulatory system that controls UV-mediated accumulation of flavonoids and UV-induced plant morphogenesis [56]. It was shown that UV-B activity reduced the content of free auxins and leaf area in Arabidopsis thaliana plants, while the content of flavonoids increased. In particular, the content of specific derivatives of campherol has increased 19-fold. Consequently, auxins are involved in UV adaptation through the flavonoid glycosylation [56]. In the cytokinin-defective mutants of Medicago truncatula (Cre1, cytokinin response 1) initiation of symbiotic nodulation occurred with the involvement of flavonoids participating in auxin transport regulation and subsequent accumulation of auxin in cortical cells [79]. It was shown that inhibition of hydroxycinnamoyl transferase activity (HCT) resulted in a reduction of A. thaliana plants height. In the HCT defective mutants, the repression of the lignin synthesis caused changes in the metabolic flavonoids flow that involved the chalcone synthase. Histochemical analysis of stem tissues in such plants demonstrated changes in the trachea elements structure. Reduction of plant height correlated with the auxin transport inhibition. The suppression of flavonoids accumulation through repression of the chalcone synthase activity in HCTs-deficient mutants restored the normal auxin transport. However, plants that had a suppressed HCT and chalcone synthase activity had the structure similar to that of HCTs-defective mutants that indicated a lack of a link between phenotype changes and a decrease in the synthesis of lignin, but only with the accumulation of flavonoids [80].

\section{Phenolic compounds - signaling molecules in the interaction of plants with rhizosphere microorganisms}

The plant rhizosphere is a dynamic ecosystem in which soil microorganisms, plant roots, abiotic and biotic components of the substrate interact $[81,82]$. Such interaction is regulated by a variety of PCs and other chemicals produced by plant roots $[83,84]$. PCs of different plant species are characterized by a certain specificity, as well as time and spatial differences [85]. PCs concentrations in the soil near the roots of monocotyledonous plants are in the range of 2.1-4.4\%, whereas in dicotyledons - 0.1$0.6 \%$ [86]. Among the plant-synthesized PCs, there are metabolites that are involved in the regulation of internal and interspecific interactions in biocenoses $[1,87]$. PCs initiate oxidation-reduction reactions in soils and selectively affect the growth and development of soil microorganisms that colonize the rhizosphere [85]. They also make an impact on the hormonal balance, enzyme activity, the presence of phytonutrients and competition between adjacent plants [88]. Individual PCs function as chemotaxis signals for soil microorganisms that recognize them and move to plant roots in a carbon-rich rhizosphere environment [89]. Flavonoids, as antioxidants and metal chelators, change the concentration of nutrients in the soil that is significant for plants, which require such elements as phosphorus and iron [90]. As a result of dynamic interaction, the structure and chemical composition of the soil vary considerably depending on the quantity and quality of phenols released by different plant species. The species of microorganisms in different parts of the roots are constantly transformed. In the rhizosphere, PCs are decomposed with the participation of microorganisms. This contributes to soil mineralization and saturation with nitrogen and humus production. [91, 92]. PCs are involved in the remote signaling of bean-rhizobial symbiosis, formation of arbuscular mycorrhizal symbiosis, and act as plant protection agents [93, 94]. During germination of legume seeds, phenolic acids and flavonoids are released from the roots [95]. The population of rhizobial bacteria in the rhizosphere changes in response to the action of PCs that accumulate in the soil that creates a competitive advantage for strains involved in the formation of root nodules [87]. PCs act as chemoattractants, which direct the rhizobial bacteria to the plant root hairs [96]. A prerequisite for the formation of root nodules is the generation of signaling molecules phenolic acids and flavonoids that are released by the roots of the legume host plants [93]. It is likely that flavonoid aglucone diffuses into rhizobial bacteria through pores [97]. Genetic studies have made it possible to establish that PCs activate numerous changes in the root hairs. Nod-factors induce the differentiation of individual cells within the root that leads to the emergence of meristematic tissue, which initiates the formation of new nodules [98]. PCs were shown to be able to affect positively and negatively signaling in bean-rhizobial symbiosis, thereby to modify nitrogen fixation. Such flavonoids as luteolin and epigene stimulated activation of the Nod-factor, while chrysene and genistein acted as phytochemical 
inhibitors in transmitting the Nod-signal [99]. Consequently, fixation of nitrogen by a nodulous bacteria can be controlled both by an effective and antagonistic phytochemical signaling by phenolic compounds.

PCs are involved in the formation of arbuscular mycorrhiza [100]. However, the role of flavonoids in such symbiosis is not entirely clear, since these compounds can exhibit both negative and positive effects on the formation of mycorrhiza. Increased biosynthesis of flavonoids during mycorrhizal development was found in the roots of Trifolium repens [101], $\mathrm{Cu}$ cumis melo [102] and Medicago truncatula [103]. During the formation of arbuscular mycorrhiza, the profile of the flavonoids of the roots changed due to changes in the expression of the genes responsible for the synthesis of phenylpropanoids [104, 105]. Exogenous flavonoids have a positive impact on the germination of spores, growth and branching of mycorrhizal fungi hyphae [100, 106]. Flavonoids are thought to stimulate the growth of fungi hyphae and to be involved in the formation of contact structures of arbuscules and vesicles responsible for the symbiotic relationship of the fungus with the host plant [107].

Phenolic compounds are plant endogenous growth regulators, the main functions of which are antioxidant, structural, attractant, signal and protective. PCs affect growth processes directly and indirectly by modulating or regulating the transport of phytohormones [77]. They act as antioxidants, inhibitors and enzyme cofactors. PCs have a positive effect on stress resistance, improve the immunity of plants. They are used as growth regulators in agriculture, prevent grain crops lodging, increase yields, and improve the quality of cultivated products. PCs application reduces the number of crops fungicides treatments during the growing season, and in some cases it appears to abandon them completely. Convincing evidence of phenols and flavonoids involvement in the formation and functioning of plant symbiosis with microorganisms has been obtained: Flavonoids are low toxic for humans, animals, plants and useful microflora, acting in low concentrations $\left(10^{-9}-10^{-6} \mathrm{M}\right)$.

PCs are used as antioxidants in dietary foods in preventing such diseases as type 2 diabetes mellitus and carcinomas [6]. The antioxidant activity of flavonoids is higher than that of vitamins C, E and carotenoids, making them the leaders among the components of herbal medicines [108]. The majority of structural and several regulatory genes of PCs biosynthesis have been identified that enabled to obtain genetically modified plants with regulated biosynthesis of phenolic metabolites [109], promising for further biotechnological developments.

The work has been carried out within the framework of the project "Phytohormonal system of new genotypes Triticum aestivum L. and its wild ancestors under effects of extreme climatic factors" (2017-2021rr), funded by the National Academy of Sciences of Ukraine No. III-82-17.454.

Conflict of interest. Authors have completed the Unified Conflicts of Interest form at http:// ukrbiochemjournal.org/wp-content/uploads/2018/12/ coi_disclosure.pdf and declare no conflict of interest.

\section{ФЕНОЛЬНІ СПОЛУКИ РОСЛИН: БІОГЕНЕЗ ТА ФУНКЦЇ̈}

\author{
Л. М. Бабенко ${ }^{1 凶}$, О. С. Смірнов², \\ К. О. Романенко, О. К. Трунова ${ }^{3}$, \\ I. В. Косаківська ${ }^{1}$
}
${ }^{1}$ Інститут ботаніки ім. М. Г. Холодного НАН України, Київ;

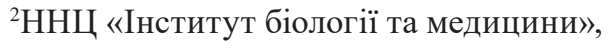 Київський національний університет імені Тараса Шевченка, Україна;
${ }^{3}$ Інститут загальної та неорганічної хімії ім. В. І. Вернадського НАН України, Київ; 凶e-mail: lilia.babenko@gmail.com

Фенольні сполуки (ФС) в рослинах відіграють значну роль у контролі росту, а також виконують важливі функції, зокрема антиоксидантну, структурну, атрактантну, сигнальну та захисну. В огляді описано історію відкриття та ідентифікації рослинних ФС, їх місце в складній системі шляхів біосинтезу вторинних метаболітів. Розглянуто функції ФС на макромолекулярному, клітинному, організменному та популяційному рівнях. Висвітлено основні етапи дослідження рослинних фенолів, розгалуження та пластичності фенольного синтезу, шляхи утворення ФС у рослинній клітині та ензими синтезу ФС. Обговорюється участь ФС в процесах дихання і фотосинтезу, окисно-відновних процесах, а також в регуляції фізіологічного стану рослин.

Ключов і слова: фенольні сполуки, фенілаланін аміак-ліаза, біогенез, фізіологічна роль. 


\section{References}

1. Prusakova LD, Kefeli VI, Belopukhov SL, Vakulenko VV, Kuznetsova SA. Role of phenol compounds in plants. Agrohimiya. 2008; 7: 8696. (In Russian).

2. Zaprometov M.N. Phenolic compounds and their role in the life of a plant: $56^{\text {th }}$ Timiryazev reading. M.: Nauka, 1996. 45 p. (In Russian).

3. Khlestkina EK. The adaptive role of flavonoids: emphasis on cereals. Cereal Res Commun. 2013; 41(2): 185-198.

4. Zaprometov MN, Nikolaeva TN. Chloroplasts isolated from kidney bean leaves are vapable of phenolic compound biosynthesis. Russ J Plant Physiol. 2003; 50(5): 623-626.

5. Zolotareva OK, Podorvanov VV, Dubyna DV. Polyphenolic compounds of macrophytes and their ecological importance. Ukr Bot J. 2017; 74(4): 373-384. (In Ukrainian).

6. Balasundram N, Sundram K, Samman S. Phenolic compounds in plants and agri-industrial byproducts: Antioxidant activity, occurrence, and potential uses. Food Chem. 2006; 99(1): 191-203.

7. Kovaleva LV, Zakharova EV, Minkina YuV. Auxin and flavonoids in the progame phase of fertilization in petunia. Russ J Plant Physiol. 2007; 54(3): 396-401.

8. Vanholme R, Demedts B, Morreel K, Ralph J, Boerjan W. Lignin biosynthesis and structure. Plant Physiol. 2010; 153(3): 895-905.

9. Amthor JS. Efficiency of lignin biosynthesis: a quantitative analysis. Ann Bot. 2003; 91(6): 673695.

10. Crozier A, Jaganath IB, Clifford MN. Phenols, polyphenols and tannins: An overview / Plant Secondary Metabolites: Occurrence, Structure and Role in the Human Diet; Crozier A, Clifford M, Ashihara H. Eds. Blackwell: Oxford, UK, 2008: 1-24.

11. Hartmann T. From waste products to ecochemicals: fifty years research of plant secondary metabolism. Phytochemistry. 2007; 68(22-24): 2831-2846.

12. Koukol J, Conn EE. The metabolism of aromatic compounds in higher plants. IV. Purification and properties of the phenylalanine deaminase of Hordeum vulgare. J Biol Chem. 1961; 236: 2692-2698.

13. Sachs, J. Handbuch der experimental-physiologie der pflanzen. Wilhelm Engelmann, Leipzig, Germany, 1865. 514 p.
14. Knaggs AR. The biosynthesis of shikimate metabolites. Nat Prod Rep. 2003; 20(1): 119-136.

15. Winkel-Shirley B. Biosynthesis of flavonoids and effects of stress. Curr Opin Plant Biol. 2002; 5(3): 218-223.

16. Hahlbrock K, Scheel D. Physiology and molecular biology of phenylpropanoid metabolism. Ann Rev Plant Physiol Plant Mol Biol. 1989; 40(1): 347-369.

17. Blount JW, Korth KL, Masoud SA, Rasmussen S, Lamb C, Dixon RA. Altering expression of cinnamic acid 4-hydroxylase in transgenic plants provides evidence for a feedback loop at the entry point into the phenylpropanoid pathway. Plant Physiol. 2000; 122(1): 107-116.

18. Allwood EG, Davies DR, Gerrish C, Ellis BE, Bolwell GP. Phosphorylation of phenylalanine ammonia-lyase: evidence for a novel protein kinase and identification of the phosphorylated residue. FEBS Lett. 1999; 457(1): 47-52.

19. Cheng SH, Sheen J, Gerrish C, Bolwell GP. Molecular identification of phenylalanine ammonia-lyase as a substrate of a specific constitutively active Arabidopsis CDPK expressed in maize protoplasts. FEBS Lett. 2001; 503(2-3): 185-188.

20. Gälweiler L, Guan C, Müller A, Wisman E, Mendgen K, Yephremov A, Palme K. Regulation of polar auxin transport by AtPIN1 in Arabidopsis vascular tissue. Science. 1998; 282(5397): 2226-2230.

21. Dai J, Mumper RJ. Plant phenolics: extraction, analysis and their antioxidant and anticancer properties. Molecules. 2010; 15(10): 7313-7352.

22. Gómez-García Mdel R, Ochoa-Alejo N. Biochemistry and molecular biology of carotenoid biosynthesis in chili peppers (Capsicum spp.). Int J Mol Sci. 2013; 14(9): 19025-19053.

23. Palladin W. Das Blut der Pflanzen. Berichte der Deutschen Botanischen Gesellschaft. 1908; 26a: 125-132.

24. Ravanel P, Tissut M, Douce R. Uncoupling activities of chalcones and dihydrochalcones on isolated mitochondria from potato tubers and mung bean hypocotyls. Phytochemistry. 1982; 21(12): 2845-2850.

25. Zhao HJ, Zou Q. Protective effects of exogenous antioxidants and phenolic compounds on photosynthesis of wheat leaves under high irradiance and oxidative stress. Photosynthetica. 2002; 40(4): 523-527. 
26. Ylstra B, Touraev A, Moreno RM, Stöger E, van Tunen AJ, Vicente O, Mol JN, Heberle-Bors E. Flavonols stimulate development, germination, and tube growth of tobacco pollen. Plant Physiol. 1992; 100(2): 902-907.

27. van der Meer IM, Stam ME, van Tunen AJ, Mol JN, Stuitje AR. Antisense inhibition of flavonoid biosynthesis in petunia anthers results in male sterility. Plant Cell. 1992; 4(3): 253-262.

28. Mo Y, Nagel C, Taylor LP. Biochemical complementation of chalcone synthase mutants defines a role for flavonols in functional pollen. Proc Natl Acad Sci USA. 1992; 89(15): 72137217.

29. Pollak PE, Vogt T, Mo Y, Taylor LP. Chalcone synthase and flavonol accumulation in stigmas and anthers of Petunia hybrida. Plant Physiol. 1993; 102(3): 925-932.

30. Boerjan W, Ralph J, Baucher M. Lignin biosynthesis. Annu Rev Plant Biol. 2003; 54: 519-546.

31 Rivero RM, Ruiz JM, García PC, LópezLefebre LR, Sánchez E, Romero L. Resistance to cold and heat stress: accumulation of phenolic compounds in tomato and watermelon plants. Plant Sci. 2001; 160(2): 315-321.

32. Król A, Amarowicz R, Weidner S. The effects of cold stress on the phenolic compounds and antioxidant capacity of grapevine (Vitis vinifera L.) leaves. J Plant Physiol. 2015; 189: 97-104.

33. Amarowicz R, Weidner S, Wójtowicz I, Karmać M, Kosińska A, Rybarczyk A. Influence of low-temperature stress on changes in the composition of grapevine leaf phenolic compounds and their antioxidant properties. Funct Plant Sci Biotechnol. 2010; 4: 90-96.

34. Weidner S, Karolak M, Karamać M., Amarowicz R. Phenolic compounds and properties of antioxidants in grapevine roots (Vitis vinifera) under drought stress followed by recovery. Acta Soc Bot Pol. 2009; 78(2): 97-103.

35. Dixon RA, Achnine L, Kota P, Liu CJ, Reddy MS, Wang L. The phenylpropanoid pathway and plant defence-a genomics perspective. Mol Plant Pathol. 2002; 3(5): 371-390.

36. Swigonska S, Amarowicz R, Król A, Mostek A, Badowiec A, Weidner S. Influence of abiotic stress during soybean germination followed by recovery on the phenolic compounds of radicles and their antioxidant capacity. Acta Soc Bot Pol. 2014; 83(3): 209-218.
37. Rudikovskaya EG, Fedorova GA, Dudareva LV, Makarova LE, Rudokovskii AV. Effect of growth temperature on the composition of phenols in pea roots. Russ J Plant Physiol. 2008; 55(5): 712715.

38. Posmyk MM, Bailly C, Szafrańska K, Janas KM, Corbineau F. Antioxidant enzymes and isoflavonoids in chilled soybean (Glycine $\max ($ (L.) Merr.) seedlings. J Plant Physiol. 2005; 162(4): 403-412.

39. Olenichenko NA, Zagoskina NV, Astakhova NV, Trunova TI, Kuznetsov YuV. Primary and secondary metabolism of winter wheat under cold hardening and treatment with antioxidants. Appl Biochem Microbiol. 2008; 44(5): 589-594. (In Russian).

40. Shichijo C, Hamada T, Hiraoka M, Johnson CB, Hashimoto T. Enhancement of red-lightinduced anthocyanin synthesis in sorghum first internodes by moderate low temperature given in the pre-irradiation culture period. Planta. 1993; 191(2): 238-245.

41. Christie PJ, Alfenito MR, Walbot V. Impact of low-temperature stress on general phenylpropanoid and anthocyanin pathways: Enhancement of transcript abundance and anthocyanin pigmentation in maize seedlings. Planta. 1994; 194(4): 541-549.

42. Gould KS, Lister C. Flavonoid functions in plants / Flavonoids: chemistry, biochemistry and applications. Eds. Andersen OM, Markham KR. Taylor \& Francis Group, LLC. 2006: 397-442.

43. Pauliuchkova SM, Spivak EA, Vershilovskaya IV, Nedved EL. The effect of exogenous 5-aminolevulinic acid on the operation of antioxidant system in potato plants (Solanum tuberosum) under low temperature stress. Proc Nat Acad Sci Belarus. Biol Ser. 2014; (3): 46-51. (In Russian).

44. Olenichenko NA, Zagoskina NV, Astakhova NV, Trunova TI, Kuznetsov YuV. Primary and secondary metabolism of winter wheat under cold hardening and treatment with antioxidants. Appl Biochem Microbiol. 2008; 44(5): 535-540.

45. Abramchik LM, Serdyuchenko EV, Makarov VN, Zenevich LA, Zhavoronkova NB, Kabashnikova LF. Varietal specific features of the reaction of the spring hexaploid triticale on thermal stress. Proc Nat Acad Sci Belarus. Biol Ser. 2014; (4): 43-49. (In Russian). 
46. Kabashnikova LF, Abramchik LM, Serdyuchenko EV, Kapylova LV. There action of barley seedlings (Hordeum vulgare) with the combined effect of hyperthermia and dehydration. Proc Nat Acad Sci Belarus. Biol Ser. 2013; (3): 60-65. (In Russian).

47. Chalker-Scott L. Environmental significance of anthocyanin in plant stress responses. Photochem Photobiol. 1999; 70(1): 1-9.

48. Gould KS, Markham KR, Smith RH, Goris JJ. Functional role of anthocyanins in the leaves of Quintinia serrata A. Cunn. J Exp Bot. 2000; 51(347): 1107-1115.

49. Harvaux M, Kloppstech K. The protective functions of carotenoid and flavonoid pigments against excess visible radiation at chilling temperature investigated in Arabidopsis npq and tt mutants. Planta. 2001; 213(6): 953-966.

50. Kolupaev YuE, Yastreb TO, Oboznyi AI, Ryabchun NI, Kirichenko VV. Constitutive and cold-induced resistance of rye and wheat seedlings to oxidative stress. Russ $J$ Plant Physiol. 2016; 63(3): 326-337.

51. Lachman J, Dudjak J, Miholova D, Kolihovas D, Pivec V. Effect of cadmium on flavonoid content in young barley (Hordeum sativum L.) plants. Plant Soil Environ. 2005; 51(11): 513-516.

52. Schmidt S, Zietz M, Schreiner M, Rohn S, Kroh LW, Krumbein A. Genotypic and climatic influences on the concentration and composition of flavonoids in kale (Brassica oleracea var. sabellica). Food Chem. 2010; 119(4): 1293-1299.

53. Treutter D. Significance of flavonoids in plant resistance: a review. Environ Chem Lett. 2006; 4(3): 147-157.

54. Babenko LM, Vodka MV, Akimov YuN, Smirnov AE, Babenko AV, Kosakovskaya IV. Specific features of the ultrastructure and biochemical composition of leaf mesophill cells of Triticum spelta L. in the initial period of stress temperature action. Cell Tissue Biol. 2019; 13(1): 70-78.

55. Kolupaev YuE, Horielova EI, Yastreb TO, Popov YuV, Ryabchun NI. Phenylalanine ammonia-lyase activity and content of flavonoid compounds in wheat seedlings at the action of hypothermia and hydrogen sulfide donor. $U k r$ Biochem J. 2018; 90(6): 12-20.

56. Hectors K, van Oevelen S, Guisez Y, Prinsen E, Jansen MA. The phytohormone auxin is a component of the regulatory system that controls
UV-mediated accumulation of flavonoids and UV-induced morphogenesis. Physiol Plant. 2012; 145(4): 594-603.

57. Murphy TM, Hamilton CM. A itrain of Rosa damascena cultured cells resistant to ultraviolet light. Plant Physiol. 1979; 64(6): 936-941.

58. Kondo N, Kawashima M. Enhancement of the tolerance to oxidative stress in cucumber (Cucumis sativus L.) seedlings by UV-B irradiation: possible involvement of phenolic compounds and antioxidative enzymes. J Plant Res. 2000; 113(3): 311-317.

59. Ou S, Lu S, Yang S. Effects of enhanced UV-B radiation on the content of flavonoids in mesophyll cells of wheat. Imaging Radiat Res. 2018; 1(1): 1-9.

60. Blokhina O, Virolainen E, Fagerstedt KV. Antioxidants, oxidative damage and oxygen deprivation stress: a review. Ann Bot. 2003; 91 Spec No: 179-194.

61. Radyukina NL, Toaima VIM, Zaripova NR. The involvement of low-molecular antioxidants in cross-adaptation of medicine plants to successive action of UV-B radiation and salinity. Russ $J$ Plant Physiol. 2012; 59(1): 71-78.

62. Punyasiri PA, Abeysinghe SB, Kumar V. Preformed and induced chemical resistance of tea leaf against Exobasidium vexans infection. J Chem Ecol. 2005; 31(6): 1315-1324.

63. Yao K, De Luca V, Brisson N. Creation of a metabolic sink for tryptophan alters the phenylpropanoid pathway and the susceptibility of potato to phytophthora infestans. Plant Cell. 1995; 7(11): 1787-1799.

64. Beckman $\mathrm{CH}$. Phenolic-storing cells: keys to programmed cell death and periderm formation in wilt disease resistance and in general defense responses in plants? Physiol Mol Plant Pathol. 2000; 57(3): 101-110.

65. Lozovaya VV, Lygin AV, Zernova OV, Li S, Hartman GL, Widholm JM. Isoflavonoid accumulation in soybean hairy roots upon treatment with Fusarium solani. Plant Physiol Biochem. 2004; 42(7-8): 671-679.

66. Dmitriev AP. Phytoalexins and their role in plant resistance. Nat. Acad. Sci. Ukraine, Institute of Cell Biology and Genetic Engineering. Kyiv: Naukova Dumka, 1999. 207 p. (In Russian).

67. Gao YN, Liu BY, Xu D, Zhou QH, Hu CY, Ge FJ, Zhang LP, Wu ZB. Phenolic compounds exuded from two submerged freshwater macrophytes 
and their allelopathic effects on Microcystis aeruginosa. Pol J Environ Stud. 2011; 20(5): 1153-1159.

68. Volynets AP. Phenolic compounds in plant life. Mynsk: Belarus. Navuka, 2013. 285 p. (In Russian).

69. Matsumura E, Matsuda M. Sato F, Minami H. Microbial production of plant benzylisoquinoline alkaloids /Natural Products: phytochemistry, botany and metabolism of alkaloids, phenolics and terpenes. Ramawat K., Mérillon JM. (Eds.). Springer, Berlin, Heidelberg, 2013: 3-24.

70. Cooper-Driver GA, Bhattacharya M. Role of phenolics in plant evolution. Phytochemistry. 1998; 49(5): 1165-1174.

71. Harborne JB, Williams CA. Advances in flavonoid research since 1992. Phytochemistry. 2000; 55(6): 481-504.

72. Wollenweber E, Stevens JF, Dörr M, Rozefelds AC. Taxonomic significance of flavonoid variation in temperate species of Nothofagus. Phytochemistry. 2003; 62(7): 11251131.

73. Erhard D, Gross E. Do environmental factors influence composition of potential allelochemicals in the submersed freshwater macrophyte Elodea nuttallii (Hydrocharitaceae)? Verh Internat Verein Limnol. 2005; 29(1): 287291.

74. Gross EM, Feldbaum C, Graf A. Epiphyte biomass and elemental composition on submersed macrophytes in shallow eutrophic lakes. Hydrobiologia. 2003; 506(1-3): 559-565.

75. Schoenaers S, Balcerowicz D, Breen G, Hill K, Zdanio M, Mouille G, Holman TJ, Oh J, Wilson MH, Nikonorova N, Vu LD, De Smet I, Swarup R, De Vos WH, Pintelon I, Adriaensen D, Grierson C, Bennett MJ, Vissenberg K. The auxin-regulated CrRLK1L kinase ERULUS controls cell wall composition during root hair tip growth. Curr Biol. 2018; 28(5): 722-732.e6.

76. Brown DE, Rashotte AM, Murphy AS, Normanly J, Tague BW, Peer WA, Taiz L, Muday GK. Flavonoids act as negative regulators of auxin transport in vivo in Arabidopsis. Plant Physiol. 2001; 126(2): 524-535.

77. Peer WA, Murphy AS. Flavonoids and auxin transport: modulators or regulators? Trends Plant Sci. 2007; 12(12): 556-563.

78. Santelia D, Henrichs S, Vincenzetti V, Sauer M, Bigler L, Klein M, Bailly A, Lee Y, Friml J,
Geisler M, Martinoia E. Flavonoids redirect PIN-mediated polar auxin fluxes during root gravitropic responses. J Biol Chem. 2008; 283(45): 31218-31226.

79. Ng JL, Hassan S, Truong TT, Hocart CH, Laffont C, Frugier F, Mathesius U. Flavonoids and auxin transport inhibitors rescue symbiotic nodulation in the Medicago truncatula cytokinin perception mutant cre1. Plant Cell. 2015; 27(8): 2210-2226.

80. Besseau S, Hoffmann L, Geoffroy P, Lapierre C, Pollet B, Legrand M. Flavonoid accumulation in Arabidopsis repressed in lignin synthesis affects auxin transport and plant growth. Plant Cell. 2007; 19(1): 148-162.

81. Yang T, Chen Y, Wang X-X, Dai C-C. Plant symbionts: keys to the phytosphere. Symbiosis. 2013; 59(1): 1-14.

82. Whipps JM. Microbial interactions and biocontrol in the rhizosphere. $J$ Exp Bot. 2001; 52(Spec Issue): 487-511.

83. Bais HP, Park SW, Weir TL, Callaway RM, Vivanco JM. How plants communicate using the underground information superhighway. Trends Plant Sci. 2004; 9(1): 26-32.

84. Dakora FD, Phillips DA. Root exudates as mediators of mineral acquisition in low-nutrient environments. Plant Soil. 2002; 245(1): 35-47.

85. Bhattacharya A, Sood P, Citovsky V. The roles of plant phenolics in defence and communication during Agrobacterium and Rhizobium infection. Mol Plant Pathol. 2010; 11(5): 705-719.

86. Hartley RD, Harris PJ. Phenolic constituents of the cell walls of dicotyledons. Biochem Syst Ecol. 1981; 9(2-3): 189-203.

87. Blum U, Staman KL, Flint LJ, Steven R. Induction and/or selection of fenolic acid utilizing bulk-soil and rhizosphere bacteria and their influence on phenolic acid phytotoxicity. $J$ Chem Ecol. 2000; 26(9): 2059-2078.

88. Hättenschwiler S, Vitousek PM. The role of polyphenols in terrestrial ecosystem nutrient cycling. Trends Ecol Evol. 2000; 15(6): 238-243.

89. Taylor LP, Grotewold E. Flavonoids as developmental regulators. Curr Opin Plant Biol. 2005; 8(3): 317-323.

90. Hassan S, Mathesius U. The role of flavonoids in root-rhizosphere signalling: opportunities and challenges for improving plant-microbe interactions. $J$ Exp Bot. 201; 63(9): 3429-3444.

91. Halvorson JJ, Gonzalez JM, Hagerman AE, Smith JL. Sorption of tannin and related phenolic 
compounds and effects on soluble-N in soil. Soil Biol Biochem. 2009; 41(9): 2002-2010.

92. Kefeli VI, Kalevitch MV, Borsari B. Phenolic cycle in plants and environment. J Cell Mol Biol. 2003; 2(1): 13-18.

93. Mandal SM, Chakraborty D, Dey S. Phenolic acids act as signaling molecules in plant-microbe symbioses. Plant Signal Behav. 2010; 5(4):359368.

94. Mierziak J, Kostyn K, Kulma A. Flavonoids as important molecules of plant interactions with the environment. Molecules. 2014; 19(10): 16240-16265.

95. Staman K, Blum U, Louws F, Robertson D. Can simultaneous inhibition of seedling growth and stimulation of rhizosphere bacterial populations provide evidence for phytotoxin transfer from plant residues in the bulk soil to the rhizosphere of sensitive species? J Chem Ecol. 2001; 27(4): 807-829.

96. Hartwig UA, Joseph CM, Phillips DA. Flavonoids released naturally from Alfalfa seeds enhance drowth rate of Rhizobium meliloti. Plant Physiol. 1991; 95(3): 797-803.

97. Kobayashi H, Naciri-Graven Y, Broughton WJ, Perret X. Flavonoids induce temporal shifts in gene-expression of nod-box controlled loci in Rhizobium sp. NGR234. Mol Microbiol. 2004; 51(2): 335-347.

98. Janczarek M, Rachwał K, Marzec A, Grządziel J, Palusinska-Szysz M. Signal molecules and cellsurface components involved in early stages of the legume-rhizobium interactions. Appl Soil Ecol. 2014; 85: 94-113.

99. Fox JE, Starcevic M, Kow KY, Burow ME, McLachlan JA. Nitrogen fixation. Endocrine disrupters and flavonoid signalling. Nature. 2001; 413(6852): 128-129.

100. Steinkellner S, Lendzemo V, Langer I, Schweiger P, Khaosaad T, Toussaint JP, Vierheilig H. Flavonoids and strigolactones in root exudates as signals in symbiotic and pathogenic plant-fungus interactions. Molecules. 2007; 12(7): 1290-1306.

101. Ponce MA, Scervino JM, Erra-Balsells R, Ocampo JA, Godeas AM. Flavonoids from shoots and roots of Trifolium repens (white clover) grown in presence or absence of the arbuscular mycorrhizal fungus Glomus intraradices. Phytochemistry. 2004; 65(13): 1925-1930.

102. Akiyama K, Matsuoka H, Hayashi H. Isolation and Identification of a Phosphate DeficiencyInduced C-Glycosylflavonoid That Stimulates Arbuscular Mycorrhiza Formation in Melon Roots. Mol Plant Microbe Interact. 2002; 15(4): 334-340.

103. Schliemann W, Ammer C, Strack D. Metabolite profiling of mycorrhizal roots of Medicago truncatula. Phytochemistry. 2008; 69(1): 112146.

104. Harrison MJ, Dixon RA. Isoflavonoid accumulation and expression of defense gene transcripts during the establishment of vesicular arbuscular mycorrhizal associations in roots of Medicago truncatula. Mol Plant Microbe Interact. 1993; 6(5): 643-654.

105. Harrison MJ, Dixon RA. Spatial patterns of expression of flavonoid/isoflavonoid pathway genes during interactions between roots of Medicago truncatula and the mycorrhizal fungus Glomus versiforme. Plant J. 1994; 6(1): 9-20.

106. Lagrange H, Jay-Allemand C, Lapeyrie F. Rutin, the phenolglycoside from eucalyptus root exudates, stimulates Pisolithus hyphal growth at picomolar concentrations. New Phytol. 2001; 149(2): 349-355.

107. Scervino JM, Ponce MA, Erra-Bassells R, Vierheilig H, Ocampo JA, Godeas A. Arbuscular mycorrhizal colonization of tomato by Gigaspora and Glomus species in the presence of root flavonoids. J Plant Physiol. 2005; 162(6): 625-633.

108. Jacobo-Velázquez DA, Cisneros-Zevallos L. Recent advances in plant phenolics. Molecules. 2017; 22(8): 1249.

109. Cartea ME, Francisco M, Soengas P, Velasco P. Phenolic compounds in brassica vegetables. Molecules. 2011; 16(1): 251-280. 